\title{
SCIENCE EDUCATORS ATTITUDES TOWARD THE NEW THEMATIC INTEGRATED CURRICULUM IN INDONESIA
}

\author{
Munasprianto Ramli \\ Pendidikan Kimia UIN Syarif Hidayatullah Jakarta, \\ munasprianto.ramli@postgrad.manchester.ac.uk
}

\begin{abstract}
Start the school year 2013/2014 the government into Indonesia through the Ministry of Education and Culture is planning to implement a new curriculum that is thematic integrative. This curriculum change dilai very rushed and poorly planned. This study aimed to explore the views of science educators in Indonesia related to curriculum implementation plan. The focus of the interviews and discussions Group researchers found that science educators hope the government would finalize percipient more attention to curriculum and other such fundamental issue competency training of teachers and science educators also hope that science subjects are not eliminated in the primary school curriculum.
\end{abstract}

Keywords: new thematic integrated curriculum, science education, science educators

\begin{abstract}
Abstrak
Mulai tahun ajaran 2013/2014 pemerintah repubik Indonesia melalui Kementrian Pendidikan dan Kebudayaan berencana mengimplementasikan kurikulum baru yang bersifat tematik integratif. Perubahan kurikulum ini dilai sangat terburu-buru dan kurang perencanaan. Penelitian ini bertujuan untuk mengeksplorasi pendapat para pendidik sains di Indonesia terkait rencana implementasi kurikulum. Dari Interview dan Fokus Gtup diskusi peneliti menemukan bahwa para pendidik sains berharap pemerintah mau lebih mematangkan persipan kurikulum dan memperhatikan maslah mendasar lainnya seperti pelatihan kompetensi guru dan pendidik sains juga berharap mata pelajaran sains tidak dihilangkan di kurikulum sekolah dasar.
\end{abstract}

Kata Kunci: kurikulum tematik, pendidikan sains, pendidik sains

\section{INTRODUCTION}

Starting from the 2013 academic year, The Indonesian Ministry of Education and Culture will implement a new integrated curriculum. There will be a major change in primary school curriculum. The government will eliminate science from primary school curriculum, and this subject will be embedded in the Indonesian language course. This study, then, explored how Indonesian science educators' response to the new primary school curriculum plan.

My interest in the subject dates back to 2001, during which I have been continuously involved in developing science education for primary school children. I was then employed during that year by the Doctorabbit Education Center, a prominent education and entertainment company in Jakarta. There, my task was to develop activities that show how that doing science can be fun, easy, and interesting.

In 2006, upon completing my master degree at McGill University, I was appointed professorship at the Faculty of Education and Teachers Training of UIN Jakarta. At the time, the department of Science Education was working on developing curriculum in Islamic primary schools. Given my academic background and research interest, I was asked to join the development team. Since then, I have been a permanent member of the project, alongside my position as a lecturer in the university. In addition, I took part in a number of workshops on developing curriculum for primary science, and seminars in curriculum development and constructivism in teaching science. For that, I was attracted to conduct this study when I hear that the Indonesian government plan to implement new curriculum which will integrate science in Indonesian language classroom at primary school. I hope that I will give a contribution to the new curriculum development in my country through this study.

This study aims to explore science educators' attitudes toward the new integrated curriculum in Indonesia. To achieve this research purpose, I addressed the following research question; how do science educators see the process of the new curriculum design and what do they perceive as the limitations and the potential problems of integrating science in Indonesian language classroom at Primary school? 
Vars (1991) states that the idea of curriculum integration has a long story, started two centuries ago when Herbert Spencers introduces a concept of core curriculum in 1800s. Vars (1991) suggests a brief definition of an integrated curriculum as an approach "to teach different subjects all deal with aspects of one topic at the same time" (Vars, 1991: 14). Jacobs (1989) as cited in Kysilka (1998) proposes five models of integrated curriculum ranging from parallel disciplines to complete integration. In line with Jacob' idea, Fogarty (1991) suggests ten ways to integrate curriculum vary from a traditional approach to completely the networked model.

In the field of science education, the curriculum integration is important to help students to be a scientifically literate person after their graduation (Crane 1991; Hurd 1999).The integration of science education and literacy can be developed through two approaches called Content Based-language Instruction (or Content Based Instruction, CBI) and Content Language Integrated Learning (CLIL). Spanos (1989) states, that content based instruction refer to cases where topical content is used in a language classroom. And, content language integrated learning is defined as an approach to teach content using the medium instruction of target language (Cambridge ESOL \& Jappinen 2005). Hapgod and Palinscar (2006) believe that children can develop language skills such as recognising letters, learning vocabulary, reading and writing when science integrated literacy is implemented.

\section{METHODS}

\section{Research Design}

Given the fact that the integrated curriculum is a new concept In Indonesia and the local publication on this topic is limited, an exploratory approach is an appropriate strategy for this study. According to Stebbins (2001), social science researchers carry out an exploratory study "when they have little or no scientific knowledge about the group process, activity or situation they want to examine (Stebbins, 2001). In order to generate data, I conducted interview and focus group discussion.

\section{Method and Participant}

For this exploratory study, I run a forty five minute semi structure interview with Professor John. I decided not to design more than fortyminute interview since Prof John is a very busy person, and he only allocated forty-five minutes for my interview. Robson (2011) argues that an interview less than thirty minutes will be invaluable while more than an hour can make unreasonable for a busy interviewee. To support the finding of interview ad as part of the data triangulation I conducted a synchronous online focus group discussion which means the participants discuss together at the same time as everyone else.

One interviewee and six participants for focus group discussion contributed to this exploratory study. All seven participants are science educators who have experiences in the field of primary science education. I selected participant using non probability sampling technique called specialist group sampling strategy. I decided to use this strategy since I want to examine the situation from experts who are able to provide rich knowledge on the issue I examined. Kerr (2012) emphasizes that specialist group sampling technique is suitable for gaining rich understanding from certain experts.

\section{Data Triangulation}

Cohen et al. (2007) defines triangulation as "the use of two or more methods of data collection in the study of some aspect of human behaviour" (Cohen et al., 2007). Lyn (1976) as cited in Cohen et al. (2007) argues that using more than one method helps the researchers to become more confident about the result of their studies. For example, the researcher can be confident when different methods generate the same result (Cohen et al., 2007). The model of my data triangulation can be seen in Figure 1 bellow.

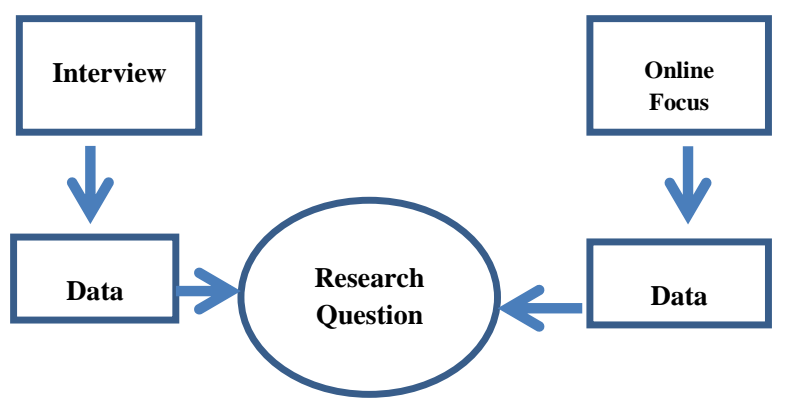

Figure 1. Model of data triangulation employed in this study.

\section{Data Recording}

Robson (2011) proposes, that taping the full interview is essential and will be beneficial for an interviewer since it provides a permanent archive and helps the interviewer to focus on an interview. For this project, I recorded the full interview and made some note as well. I wrote key words from the interviewee to check my understanding by 
develop further question based on the key word arise from the interviewee. Data from online focus group was recorded using copy and paste technique.

\section{Theoretical Sensitivity}

Strauss \& Corbin (1990) suggest that theoretical sensitivity is a personal quality of researcher which indicates the ability to seek the meaning of important data. Theoretical sensitivity is "the attribute of having insight, the ability to give meaning to data the capacity to understand, and capability to separate the pertinent from that which isn't" (Strauss \& Corbin 1990).

According to Strauss and Corbin, theoretical sensitivity comes from several sources includes; research literature, professional experience, personal experience and analytic process. Since, I did not use any theoretical framework, I seek the meaning of my data using the literature, my professional experiences and analytic process. I interpreted the data based on my experience in the field of science education in Indonesia as a science educator and discover and thought about variation and differences when I interacted with data.

\section{Data Analysis}

There are several approaches can be used in analysing qualitative data, such as discourse analysis, narrative analysis and thematic analysis. For this study I employed thematic analysis approach. Boyatzis (1998), defines thematic analysis as a process used in qualitative research for encoding qualitative information. Boyatzis then suggests that thematic analysis 'can be used as a way of seeing, a way of making sense, a way of analysing qualitative information, a way of systematically observing, and a way of converting qualitative information into qualitative data'(Boyatzis, 1998). In line with Boyatzis, Braun \& Clarke (2006) reveal that thematic analysis is a method for identifying, analysing and reporting themes in qualitative data.

Thematic analysis is one of approaches that widely used in qualitative analysis (Braun \& Clarke, 2006; Howitt \& Cramer 2011). Howitt \& Cramer (2011) believe that thematic analysis is favour by newcomers in qualitative research since it required less knowledge in theoretical underlying the methods. There is no agreement in the reason why and how one conducting thematic analysis (Braun \& Clarke, 2006; Howitt \& Cramer, 2011). However, Boyatzis (1998) and Braun \& Clarke
(2006) develop a guidance in using thematic analysis.

Boyatzis (1998) introduces three different stages in conducting thematic analysis, includes; sampling and design issues, developing themes and a code, and validating and using the code. Similar with Boyatzis, Howitt \& Cramer (2011) suggest three basic process of thematic analysis: transcribing textual material, analytic effort and identifying themes and sub-themes. Furthermore, Braun and Clarke (2006) provide more comprehensive strategies for thematic analysis. According to Braun and Clarke, thematic analysis can be conducted in 6 steps which are familiarisation with the data, initial code generation, searching for themes, reviewing themes, defining and naming themes and report writing.

Adapting the strategies from above scholars, I developed my own thematic analysis model for this study. I divided my thematic analysis into three phases which are from data to coding, themes generation and from themes to report. My model of thematic analysis is summarized in the Figure 2 bellow.

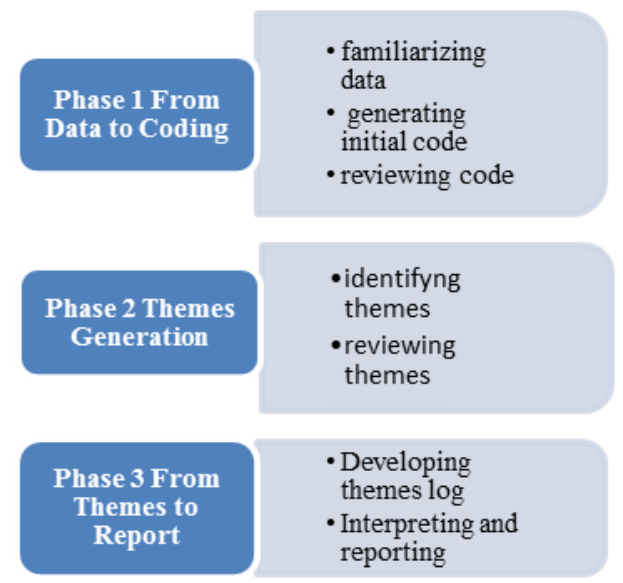

Figure 2. Model of Thematic Analysis

\section{Phase 1 From Data to Coding}

a. Familiarizing Data

Since I collected data by myself, this step is an on-going process. During this early step I did three activities as suggested by Robson (2011) and Braun \& Clarke (2006). Firstly, I transcribed the recording data from my interview. I did full transcription for my interview. What I mean by full transcription is I transcribe the entire interview recording. The transcription process was time consuming since I translated the interview from Indonesian language to English. It took me a day to transcribe the interview recording. However, I did 
not transcribe the focus group discussion since working from the original data is feasible (Robson, 2011).

After transcribing the recording, I read my interview transcript while listening to original recording. In order to familiar with the depth and breadth of the content, I did repeated reading. As can be seen from Figure 3 .

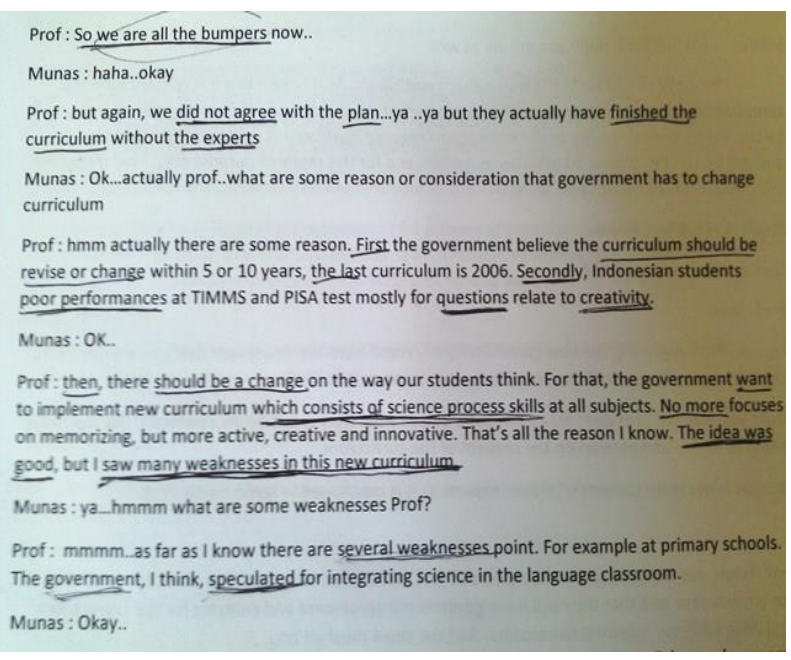

Figure 3.Marking key words

During re-reading process I started marking ideas by underlying key words which needed for initial coding. Similar with transcription process, reading and repeated reading was time consuming.

\section{b. Generating Initial Codes}

Saldana (2009) suggests that code in qualitative analysis is 'most often a word or short phrase that symbolically assigns a summative, salient, essence-capturing, and/or evocative attribute for a portion of language-based or visual data' (Saldana, 2009). In line with Saldana, Boyatzis (1998) proposes that code is an element that capture the qualitative richness of phenomenon and usable in analysis, interpretation and presentation of the research (Boyatzis, 1998).

To develop thematic codes, Boyatzis (1998) proposes three different ways. First, the researcher can develop code from the theory (theory driven code). By using this strategy, the code can be generated from the hypothesis or element of the theory. Next, one can use literature or prior research in developing thematic code (Prior research driven code). Finally, the researcher develops code from raw information in the data (inductive data driven code).

Since I did not use any theoretical framework and lack of publication in the similar topic in Indonesia, I decided to use a data-driven code in bold font and letter a, b, c and d (see Table 1 and 2).

\section{c. Reviewing Code}

This stage is conducted manually by reading and re-read the printed version of initial codes and listening to the original recording. Should there was a change in a code, I revised initial codes and draw a new table for initial and revision codes. The example of this process can be seen in the figure 4 and Table 3.

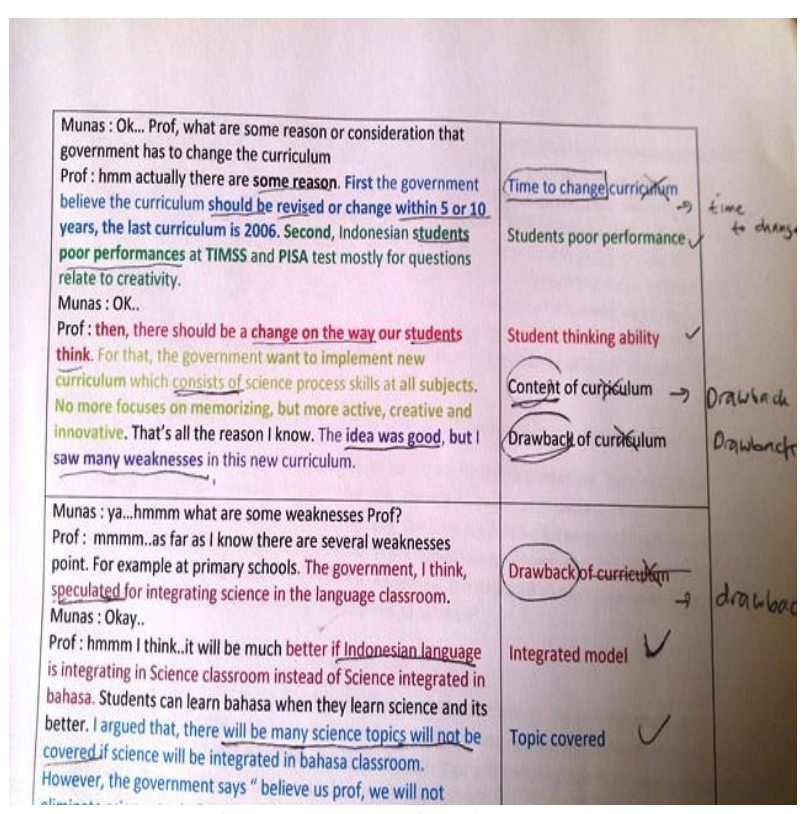

Figure 4 . Reviewing Code

After having a revised code which I satisfied with, I decided to code certain part of focus group discussion data which potential to support the interview data. I did repeated reading before choosing the data which are similar in term of word, phrase and content to the interview data. Example of the potential data and codes from online focus group discussion can be seen in the Table 4. 
Munas : Prof, regarding the new curriculum plan, I read from the newspaper that you are one of the experts who are in curriculum committee, what is this team called? Prof : -Yes, the vice president asked me to be one of what they called board of advisor-(a). -Our main role is to give advice and opinion on the content of the curriculum-(b).

Munas : Is the team consists of eleven experts as it is mentioned in some media Prof?

Prof : hmm, -Yes there were eleven experts at first, but the number then decreased for no reason-(a). -The government said that they will issue government agreement and contract for the experts, but until now, I did not receive it hahahahha...but the show must go on-(b).

Munas : hahahhaa, as usual Prof?

Prof : yes hahahha, at last there were 8 experts on the board.-We have a meeting every Thursday but most of the experts are on-off-on off because they are busy, only me and other two professor from ITB who always came. Mr Awan, Most of the time did not show up. Mr. Abas and Mrs Rina did not come at several meeting-(a). Eventhough, all the experts did not regularly come and did not agree with the change, the government put them as "the buffer" for the public trial of new curriculum hahaha(b)

Munas : hahaha

Prof : like yesterday, I came to one of public trial

Munas : he eh..

Prof : -Public asked many questions on the new curriculum almost about everything, and the team from government includes vice minister just simply replied that the new curriculum has been analysed, criticized and reformulated by experts from different fields, include Prof John, Mrs Rina, Mr Abas, Mr Awan etc..so eventhough the experts did not agree with the plan, the government keep inform the public that we are supports the new curriculum...hahahaha-(c)

Interviewer : hahaha

Prof : -so most of the people simply accept that. The public thought that if curriculum has supported by Prof John, Mrs Rina, Mr Abas, Mr Awan we do not need to worry hahhaha-(d)

\author{
(a)Board of advisor \\ (b)Board responsibility
}

(a)Elimination team members

(b)Unsigned contract

(a)Nature of the team

(b)Experts as a buffer

(c)Experts as a buffer

(d)Talked about people opinion

Table 2. Identifying code using alphabet

Interview Transcript

\footnotetext{
Munas : Ok... Prof, what are some reason or consideration that government has to change the curriculum

Prof : hmm actually there are some reason. -First the government believes the curriculum should be revised or change within 5 or 10 years, the last curriculum is 2006-(a). -Second, Indonesian students poor performances at TIMSS and PISA test mostly for questions relate to creativity-(b).

Munas : OK..

Prof : -then, there should be a change on the way our students think-(d). -For that, the government want to implement new curriculum which consists of science process skills at all subjects. No more focuses on memorizing, but more active, creative and innovative-(e). That's all the reason I know. -The idea was good, but I saw many weaknesses in this new curriculum-(f).
}

Initial Coding

(a)Time to change curriculum

(b)Students poor performance

(c)Student thinking ability

(d)Content of curriculum

(e)Drawback of curriculum 
Table 3.Initial and Revision Codes

\begin{tabular}{|c|c|c|c|}
\hline Initial codes & Revision Codes & Initial Codes & Revision Codes \\
\hline Board of advisor & Board name & Teachers preparation & NR \\
\hline Board responsibility & Responsibility & Worrying the preparation & NR \\
\hline $\begin{array}{l}\text { Elimination team } \\
\text { members }\end{array}$ & $\begin{array}{l}\mathrm{NR} \\
\mathrm{NR}\end{array}$ & $\begin{array}{l}\text { Communication of board } \\
\text { member }\end{array}$ & NR \\
\hline Unsigned contract & Meeting schedule & Approaching minister & NR \\
\hline Nature of the team & Experts as a buffer & Teachers condition & Teaches quality \\
\hline Talked Experts as a & People opinion & & NR \\
\hline $\begin{array}{l}\text { buffer } \\
\text { Talked about people }\end{array}$ & Reality & $\begin{array}{l}\text { Scientific literacy skills } \\
\text { Government plan }\end{array}$ & $\begin{array}{l}\mathrm{NR} \\
\mathrm{NR}\end{array}$ \\
\hline $\begin{array}{l}\text { opinion } \\
\text { Reality in designing } \\
\text { curriculum }\end{array}$ & $\begin{array}{l}\text { Time to change } \\
\text { NR }\end{array}$ & Students' poor performance & $\begin{array}{l}\text { Students' poor } \\
\text { performance (prediction) }\end{array}$ \\
\hline $\begin{array}{l}\text { Time to change } \\
\text { curriculum }\end{array}$ & $\begin{array}{l}\text { NR } \\
\text { Content }\end{array}$ & $\begin{array}{l}\text { Approaching vice president } \\
\text { Text book for new curriculum }\end{array}$ & N.R \\
\hline $\begin{array}{l}\text { Students' poor } \\
\text { performance }\end{array}$ & $\begin{array}{l}\mathrm{NR} \\
\mathrm{NR}\end{array}$ & $\begin{array}{l}\text { Ideal scheme for producing } \\
\text { text books }\end{array}$ & Text books \\
\hline Student thinking ability & NR & inexperienced author & Scheme for text books \\
\hline $\begin{array}{l}\text { Content of curriculum } \\
\text { Drawback of curriculum }\end{array}$ & NR & $\begin{array}{l}\text { Example of integrated } \\
\text { curriculum }\end{array}$ & N.R \\
\hline $\begin{array}{l}\text { Integrated model } \\
\text { Topic covered }\end{array}$ & $\begin{array}{l}\text { NR } \\
\text { Teaching methodology }\end{array}$ & $\begin{array}{l}\text { Misleading on } \\
\text { curriculum development }\end{array}$ & N.R \\
\hline Eliminated topic & Assessment criteria & Curriculum draft & Inconsistency \\
\hline $\begin{array}{l}\text { People perception on } \\
\text { science }\end{array}$ & NR & $\begin{array}{l}\text { Issue on board role } \\
\text { Pending }\end{array}$ & NR \\
\hline Problem with teaching & Assessment criteria & Ideal implementation & NR \\
\hline methodology & NR & Curriculum supplement & NR \\
\hline $\begin{array}{l}\text { Different assessment } \\
\text { criteria }\end{array}$ & $\begin{array}{l}\text { NR } \\
\text { Pilot project }\end{array}$ & & $\begin{array}{l}\text { NR } \\
\text { NR }\end{array}$ \\
\hline Questioning the criteria & NR & & \\
\hline $\begin{array}{l}\text { used } \\
\text { Mixed assessment }\end{array}$ & $\begin{array}{l}\mathrm{NR} \\
\mathrm{NR}\end{array}$ & & \\
\hline $\begin{array}{l}\text { criteria } \\
\text { Pilot Project }\end{array}$ & NR & & \\
\hline No Pilot project & & & \\
\hline Comparative study & & & \\
\hline Public trial issue & & & \\
\hline Public trial participants & & & \\
\hline Teachers quality & & & \\
\hline
\end{tabular}

Table 4. Example of Online Focus group discussion data

Transcript

Code

Dari : kemampuan guru SD sangat tidak merata. Saya duga penyusunnya tidak pernah Teachers quality punya data atau tidak mau tahu data kualitas guru dalam proses pembelajaran, proses tematik pada KTSP saja itu "gagal" apalagi ini akan kelas 1-6.

( the quality of primary teachers are vary, and I don't think the curriculum designers have a data about the quality of primary teachers. Many teachers failed to implement current curriculum, and it will be the same with the upcoming curriculum)

Oke: saya khawatir uji publik hanya formalitas, dan untuk kesiapan guru juga saya tidak yakin. karena pengalaman saya mengajar guru-guru SD, mereka mengintegrasikan biologi, fisika, dan kimia saja masih penuh tanda tanya.

(I am worrying that the public trial is a formality event only and I am not sure with teachers' preparation. Some of our primary teachers are struggling for integrating biology ad physics content, how will they integrate science in language classroom? ). 


\section{Phase 2 Themes Generation}

\section{a. Identifying Themes}

Braun \& Clarke (2006) define themes as a major pattern in initial coding which can be generated by coding the initial code. In other words, theme is a 'second level of interpretation of the text where the analyst focuses on the relationship between the coding' (Braun \& Clarke, 2006).As suggested by Robson 2011, I sorted different coding into potential themes by seeking the relevance, similarities and differences between the coding. I printed the initial codes in a paper which I called spread coding page. I made a connection line between the codes to identify potential themes for codes which lead to certain themes. The process can be seen in the Figure 5 below.

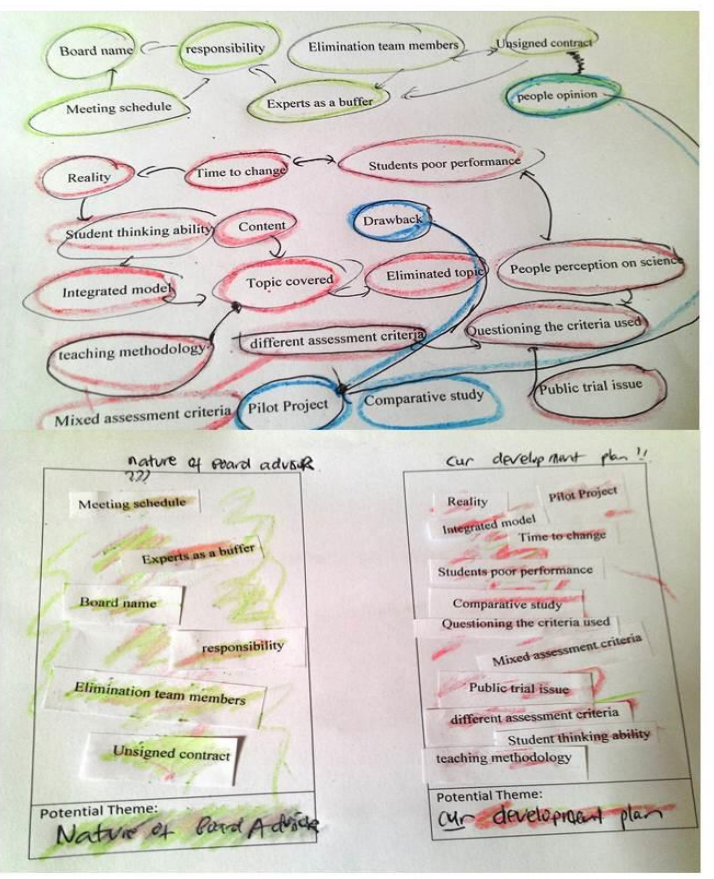

Figure 5. Code spreading page and potential themes

After having the potential theme, I drawn my theme map as can be seen in the Figure 6 below.

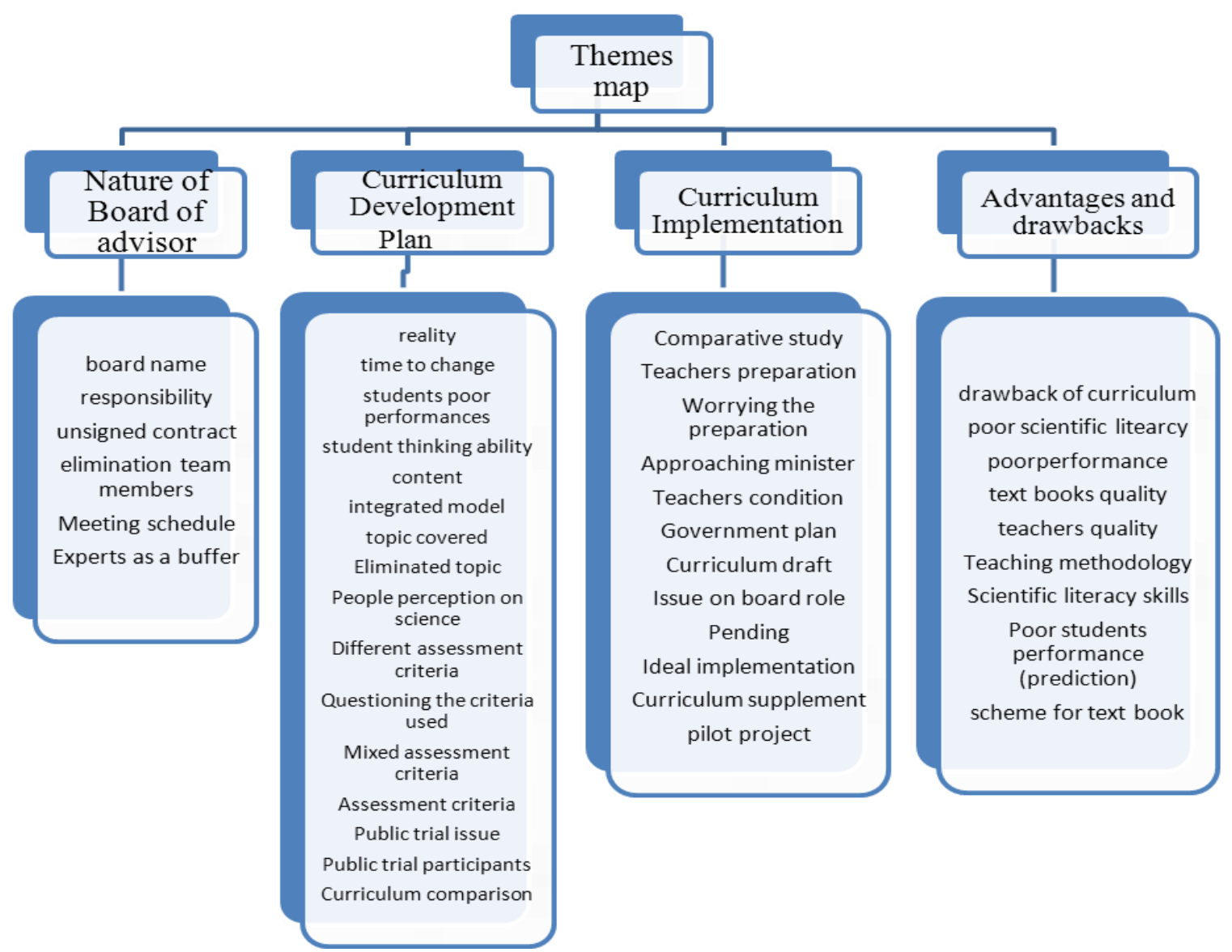

Figure 6.Thematic map 


\section{b. Reviewing Themes}

At this stage, I reviewed the themes I had from the previous stage by checking the themes with transcript and original data (recording and documents of online focus group discussion). The reviewing process is needed for some reasons, includes: there is not enough data to support themes so the themes need to be modified, there is may be more than one main point in the themes so themes need to be split into two or more, and the themes may too broad and does not fit to the data so need to find a new theme (Braun \& Clarke, 2006; Robson 2011)

In reviewing themes, I do repeated reading and repeated listening to original data. I worked manually with my thematic map and I found two themes that may overlap and one can be a sub theme instead of themes. Then, I modify the first model of my thematic map to the second model of my thematic map that I satisfied. The figure 7 shows the revision version of my thematic map.

\section{Phase 3 From Themes to Report}

Developing Themes Log

After having the satisfied themes, I decided to develop a document what I called themes log. This document will make the next stage (interpretation and discussion) become easier. The Themes $\log$ is document which contains the themes, sub-themes if applicable, themes definition and the evidence. The example of my themes log can be seen in Figure 8 below.

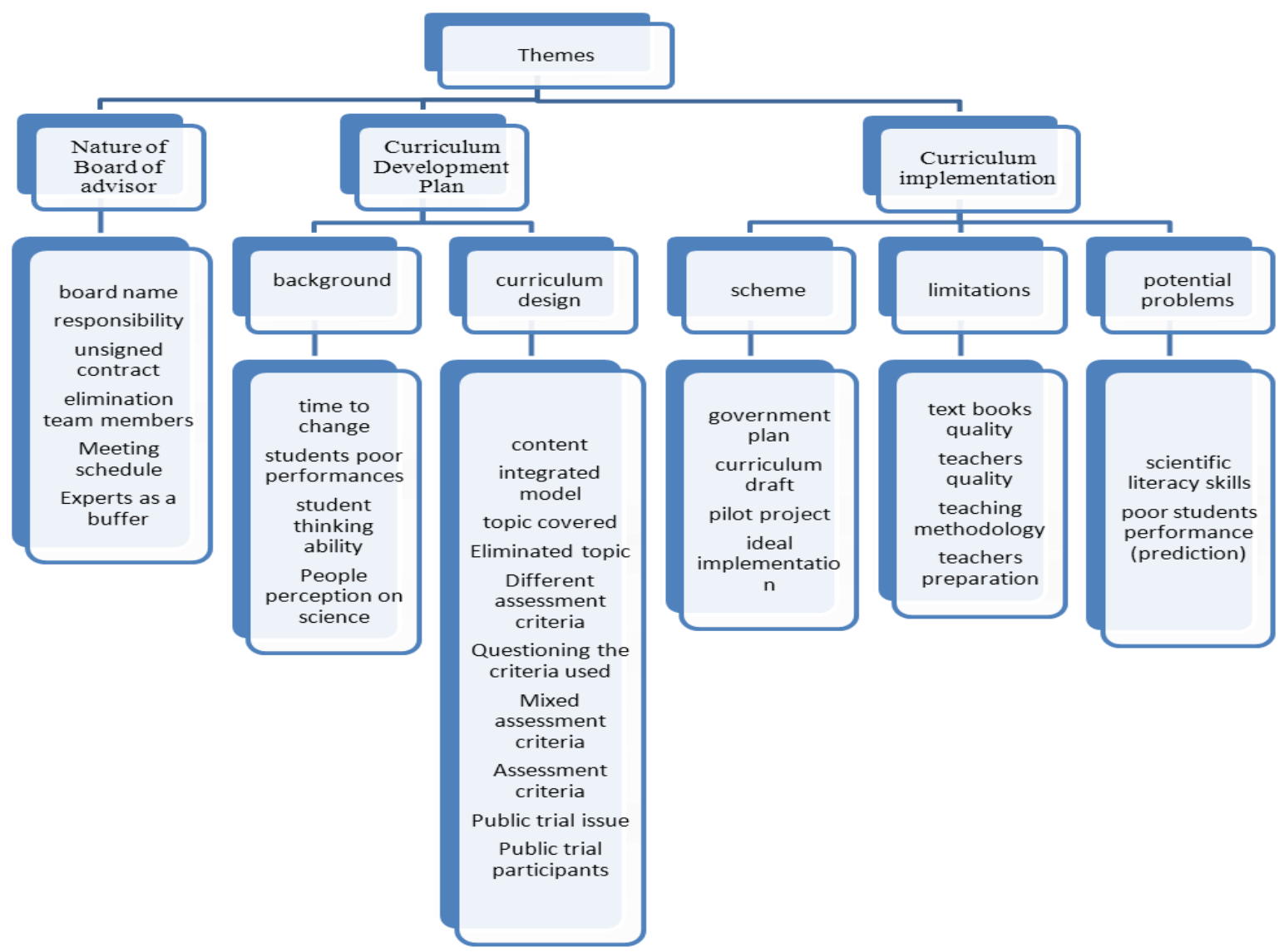

Figure 7 Revision version of thematic map 


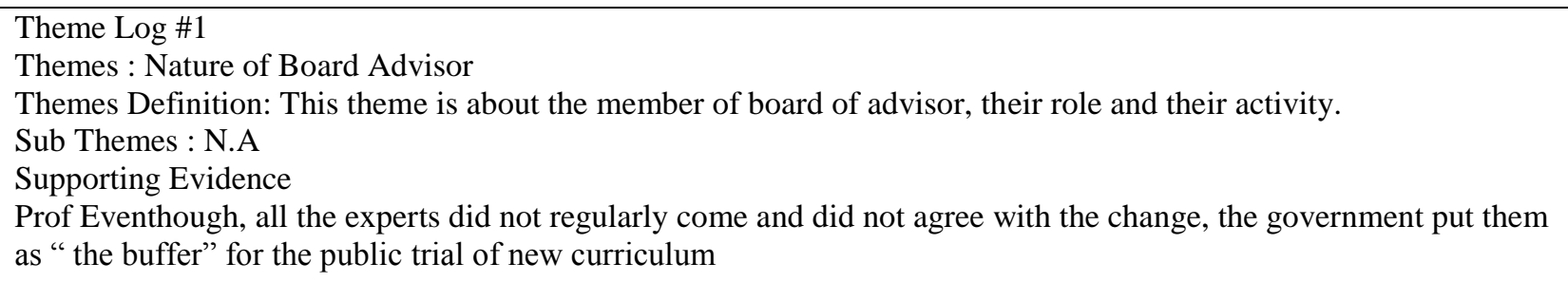

Theme Log \#2

Themes : Curriculum Development plan

Themes Definition: This theme is about the background of the new curriculum, the stage of curriculum design, content of curriculum and public trial.

Sub Themes 1. : Background

Supporting Evidence

Prof : First the government believe the curriculum should be revised or change within 5 or 10 years, the last curriculum is 2006. Second, Indonesian students poor performances at TIMSS and PISA test mostly for questions relate to creativity.

......

Sub Themes 2. : Curriculum Design

Supporting Evidence

Prof John : hmmm I think..it will be much better if Indonesian language is integrating in Science classroom instead of Science integrated in bahasa. Students can learn bahasa when they learn science and its better. I argued that, there will be many science topics will not be covered if science will be integrated in bahasa classroom. However, the government says " believe us prof, we will not eliminate science topics" and I replied.."it is almost impossible that all science topics will be covered if such integration is implemented. And when the government published the draft, we can see that around 70 of science topics were eliminated. There is no topic about, earth, electricity, sounds, simple tools. I told the government, it is what I worried about.

Theme Log \#3

Themes : Curriculum Implementation

Themes definition: This theme is about the scheme of curriculum implementation and science educators perception on limitation and potential problems.

Sub Themes 1. : Scheme

Supporting Evidence

Prof : , In my opinion if the ministry want to introduce new curriculum he should prepare it within 3-4 years..the first year the ministry planning for the new curriculum and conducting public trial, then the second year conducting pilot projects at some school, do monitoring and evalution, so at the end of the fourth years the new curriculum is ready. The ministry then launching the new curriculum at the last year of his periods and the following Minister should continue the curriculum until it is needed to change or revise the curriculum..It is not like what happen today

Sub Themes 2. : Limitation

Supporting Evidence

Prof John : To date, most of the teachers have a problem with methodology of teaching primary science mmmm and now, the government does a frontal change. I am questioning how the government will conduct a massive teachers training, since it is around millions of teacher should be trained

\section{Figure 8. Example of Themes Log}

The final stage of data analysis is interpretation and discussion which will be discussed in the next section.

\section{INTERPRETATION AND DISCUSSION}

\section{a. Nature of Board of Advisor}

In order to enrich the quality of the new curriculum, Indonesian government ask some experts to be a member of board of advisor for the new thematic curriculum. The board of advisor has a role to give an advises and opinion about the content of new curriculum. Involving experts in designing curriculum is important since they play central role in curriculum formation (Westbury 2008). However, the experts sit in the board of advisor for Indonesian new Curriculum was not playing their function as it is should be. As Professor John reveals that "We have a meeting every Thursday but only me and other two professor from ITB who always came. Mr Awan did not show up most of the time. Mr. Abas and Mrs Rima did not come for several meeting". 
Moreover, there was an indication that government need some experts to involve in curriculum formation to back the government up from the public debate. The government need figures to convince the society on the curriculum change, but they did not pay full attention to the experts' thoughts. As Professor John states "We seem so vocal during the meeting. When we delivered many advices and suggestion, the ministry team pay serious attention and listen to each advisor. However, it seems they already had their draft. They listen for the advisors speech but did not take any response to them". To show that government need the back up, He says "Public asked many questions on the new curriculum almost about everything, and the team from government includes vice minister just replied that the new curriculum has been analysed, criticized and reformulated by experts from different fields, include Prof John, Mrs Rima and Prof Abas. So even though the experts did not agree with the plan, the government keep inform the public that we are supports the new curriculum", "So most of the people simply accept that. The public thought that if curriculum has supported by Prof John, Prof Abas and Mrs Rima, They do not need to worry".

\section{Curriculum Development Plan}

Curriculum change has been a major issue in last several decades all over the world (Blenkin et al., 1992). There are several reasons for changing curriculum, in the current change in Indonesia, the interviewee mentioned that the government has three reasons to develop new curriculum. Firstly, the government believe that the curriculum should change periodically and it has been almost ten years since the last curriculum being implemented. Prof John states that "the government believe the curriculum should be revised or change within 5 or 10 years, the last curriculum has been implementing from 2006". Without any reports on the result of the evaluation of the last curriculum, the government plan to implement new curriculum is questionable. Ms Dari, a participant of the online focus group discussion says that "The government plan is only based on their assumption. The government force to implement new curriculum without any prior research". In line with the participants arguments, Westbury (2008), notes that most policy decision in education, including curriculum decision, are made with little or no public attention and The dynamics of government are not well understood by most people outside the government" (Westbury, 2008).
Secondly, the government want to change the curriculum to improve Indonesian students' performance at The Trends in International Mathematics and Science Study (TIMSS) and The Programme for International Student Assessment (PISA). TIMSS is an international assessment for math and science of $4^{\text {th }}$ and $8^{\text {th }}$ grade students all over the globe and PISA is assessment for math, science and reading of 15 years old students around the world. The results of Indonesian students at the last of both assessments were very poor. Indonesian was at the rank 40 out of 42 countries for Mathematic ((Mullis et al 2012)), 38 out of 42 for science at the TIMSS 2011 (Martin et al 2012) and rank 57 out of 65 for PISA ( http://www.oecd.org/pisa/). Finally, as state by Prof John, "the government want to change the way students think, no more memorizing but more active creative and innovative".

Ornstein \& Hunkins (2009), as cited in O'Neill (2010), suggest that curriculum development should be encompasses on planning, process and procedure in designing, implementation and evaluation of curriculum. In line with this argument, the Indonesian Ministry of Education and Culture (2012), develop the new integrated curriculum into four stages, includes: designing the draft by involving experts, presenting the draft at the People Representative Council's Meeting, public trial and finalization of the draft. However, the government develop the stages in inappropriate way.

The interviewee reveals that the government come with their draft without considering the experts' thought. For example, Prof John states that hmmm "I think..it will be much better if Indonesian language (Bahasa) is integrating in Science classroom instead of Science integrated in Bahasa. Students can learn Bahasa when they learn science and its better. I argued that, there will be many science topics will not be covered if science will be integrated in Bahasa classroom. However, the government says "Believe us Prof, we will not eliminate science topics" and I replied "it is almost impossible that all science topics will be covered if such integration is implemented. And when the government published the draft, we can see that around 70 of science topics were eliminated. There is no topic about, earth, electricity, sounds, and simple tools. I told the government, it is what I worried about".

Moreover, a public trial as a crucial stage in designing the new curriculum is only a formality 
event. The interviewee states that the government has their own agenda regardless for whatever of public trial. The most of the participants attended the public trial has a connection with the ministry. Prof John says that "some people critique the new curriculum but around $70 \%$ of the public trial participants is the ministry of education staff, so the majority were agree with the new curriculum". Similar with him, an online group discussion participant states that the participants of the public trial mostly are school principal, the head of education foundation and ministry of education staff.

\section{b.Curriculum Implementation Plan}

As discussed above, Ornstein and Hunkins argue that the curriculum developer should emphasize the process and procedure of the implementation as a part of curriculum development. However, the interview and focus group discussion indicate that the Indonesian Ministry of Education and Culture did not pay careful attention to the process. They did not follow the suitable scheme for curriculum intervention. The interviewee states that "the mistakes is on the process, in my opinion if the new minister want to introduce new curriculum he should prepare it within 3-4 years..During the first year, the ministry planning for the new curriculum and conducting public trial, then the second year conducting pilot projects at some school, do monitoring and evaluation, so at the end of the fourth years the new curriculum is ready. The minister then launching the new curriculum at the last year of his periods and the next minister should continue the curriculum until the time/grass root called to change or revise the curriculum. It is not like what happen today".

Ornstein \& Hunkins (1988), proposed that one factor should be considered in implementing curriculum is the organic approach which means the bureaucratic should pay serious attention to grassroots problems. Moreover, Ornstein and Hunkins reveal that the teachers can be persistence to deliver new curriculum change should they do not have a clear picture on the purpose of the change and the load of the works as a result of change. In line with this argument, teachers in Indonesia have limitation to response a rapid change. The online focus group discussion notes that "Some of our primary teachers are struggling for integrating the content of basic biology and basic physics, how will they integrate science in language classroom?".
Teachers quality and teachers preparation are other limitation aspects which government should focus on. Prof John is questioning whether the teacher will be able to deliver new curriculum and the government able to manage huge teachers training, " most of the teachers have a problem with methodology of teaching primary science and now, the government does a frontal change. I am questioning how the government will conduct a massive teachers training, since it is around millions of teacher should be trained".

Examining the process and procedure of curriculum design, science educators predict that it will be difficult to achieve a goal of improving Indonesian students' performance at TIMSS and PISA when the new integrated curriculum is implemented. By eliminating science in primary school, government shows an incoherent strategy. As can be seen from the transcript, the interviewee argues that "But I don't think our students will be able to answer PISA questions. The PISA Questions need creative thinking.mmm see this, around $70 \%$ science's content will be eliminated, what can we $d o$ ? ". Similar with the interviewee the participant of online group discussion believe that "the Indonesian rank in TIMSS and PISA will be going down should the government force to implement the new integrated curriculum"

Scientific illiterate generation is another potential problem that may occur if science is integrated in Indonesian language classroom. Prof John argues that Indonesian students will not be able to understand science articles in magazine and newspaper, "How will they be able to understand if they have less knowledge? It will be demotivated students...mmm as the results students will not like science, and they do not want to be scientist. So we will be far behind developed country in the field of science and technology".

To conclude, Indonesian government want to implement new integrated curriculum to improve students' performance and develop student's thinking skills. To achieve this goal the government will integrate science into Indonesian language classroom. However, science educators have a different perspective. Science educators believe that the integrated could lead to scientific illiterate generation which will influence students' performance at the TIMSS and PISA. In order to prevent the potential problems, the interviewee states that the board of experts will approach the Minister and Vice President to postpone the implementation or to conduct pilot project at 
several schools instead of implementing the new curriculum all over Indonesia simultaneously.

\section{REFERENCE}

Boyatzis RE. 1998. Transforming Qualitative Information: Thematic Analysis and Code Development. Thousand Oaks : Sage Publication.

Blenkin GM .1992. Change and the Curriculum. London: Paul Chapman Publishing.

Braun V, Clarke, V. 2006. Using thematic Analysis in Psychology. Qualitative Research in Psychology 3(2):77-101.

Crane S. 1991. Integrated Science in a Restructured High School. Educational Leadership 49(2): $39-41$.

Cohen L, et al. 2007. Research Methods in Education. New York: Routlegde.

Fogarty R. 1991. Ten Ways to Integrate Curriculum. Educational Leadership 49(2):61-65.

Hapgod S, Palinscar S. 2006. Where literacy and Science Intersect. Educational Leadership 64(4):56-60.

Howitt D, Cramer D. 2011. Introduction to Research Methods in Psychology. Harlow: Perason Education Limited.

Howes AJ. 2013. Qualitative Data Analysis Module. EDUC 60562 Qualitative Data Analysis. University of Manchester. Available from : Blackboard.

Hurd PD. 1999. Why We Must Transform Science Education. Educational Leadership 49(2):33-35.

Kysilka ML. 1998. Understanding Integrated Curriculum. Curriculum Journal 9(2):197209.

Jappinen A. 2005. Thinking and Content Learning of Mathematics and Science as Cognitional of Development in Content and Language. Language and Education 19(2):147-168.

Kerr K. 2012. Combining Methods. EDUC 60531 Data Generation : Qualitative Methods. University of Manchester, Ellen Wilkinson Building on 13 November 12012 Available from : Blackboard.

Kerr K. 2012. Sampling Strategies EDUC 60500 Planning of Research. University of
Manchester, Ellen Wilkinson Building on 15 November. Available from: Blackboard.

Martin MO, et al. 2012. TIMSS 2011 International Results in Science. Chestnut Hill : TIMSS and PIRLS International Study Centre. (Available at : http://timssandpirls.bc.edu, accessed on April 30, 2013)

Mullis IV, et al. 2012. TIMSS 2011 International Results in Mathematics. Chestnut Hill : TIMSS and PIRLS International Study Centre. (Available at : http://timssandpirls.bc.edu, accessed on April 30, 2013)

Nes FV, et al. 2010. Language Differences in Qualitative Research: is meaning lost in translation. European Journal of Ageing 7(4):313-316.

OECD Program for International Student Assessment . 2010. PISA 2009 Results: What students Know and Can Do: Students Performance on Reading, Mathematics and Science. (Available at : http://oecd.org, accessed on April 30, 2013)

Ornstein AC, Hunkins FP. 1998. Implementing Curriculum Change: Guideline for Principals. NASSP Bulletin November 1988 pp 67-72.

O’Neil G. 2010. Program Design : Overview of Curriculum Model. University College Dubline. Available at: http://www.ucd.ie accessed on April 20 2013)

Robson C. 2011. Real World Research. Chicester : John wiley \& Sons Ltd.

Saldana J. 2009. The Coding Manual for Qualitative Researchers. Thousand Oaks: Sage Publication.

Spanos G. 1989. On the Integration of Language and Content Instruction. Annual Review of Applied Linguistic 10:227-240.

Stebbins RA. 2001. Exploratory Research in the Social Sciences. California: Sage Publications.

Tracy, Sarah J. 2010. Qualitative Quality: Eight "Big-Tent" Criteria for Excellent Qualitative Research. Qualitative Inquiry 16(10):837851. 
University of Cambridge ESOL Examination (n.d). Teaching Science Trough English a CLIL Approach. Cambridge; University of Cambridge ESOL examination. (Available at: https://www.teachers.cambridgeesol.org accessed on December 20 2012)
Vars RF. 1991. Integrated Curriculum in Historical Perspective. Educational Leadership 49(2):14-15.

Westburry I. 2008. Curriculum in Practice. In: Connely, FM. The Sage Handbook of Curriculum and Instruction. Thousand Oaks: Sage Publication. 
Science Educators Attitudes Toward The New Thematic Integrated Curriculum in Indonesia 